\title{
Measuring the social market economy. A composite index approach for EU countries
}

\author{
Adriana AnaMaria DAVIDESCU \\ The Bucharest University of Economic Studies, Bucharest, Romania \\ National Scientific Research Institute for Labour and Social Protection, Bucharest, Romania \\ adrianaalexandru@yahoo.com
}

\begin{abstract}
The main objective of the paper was to construct a synthetic measure that can be used as benchmark for measuring the progress toward convergence to the social market economy as specification of the Lisbon Treaty. This kind of approach will enable us to identify the main determinants of the social market economy among EU member states using a principal component analysis technique (PCA) analyzing comparatively different group of countries. The analysis was conducted at the level of the 28 EU countries for the year 2013 using 15 indicators from four categories: efficient market allocation, efficient property rights, economic and ecological sustainability and social inclusion. The empirical results revealed that the key determinants in explaining the social market economy at European level are freedom of contract, open markets, financial stability and effective environmental protection and highlighted Sweden, Finland, Denmark, Estonia and Germany as the main poles of social market economy at European level while at the opposite side Romania, Hungary and Bulgaria registered the smallest level of social market economy. As main contribution brought by the paper there can be mentioned the attempt of measuring the level of social market economy at European level using an aggregate composite index for the level of 2013 highlighting the main poles of social economy.
\end{abstract}

Keywords: social market economy, principal component analysis, composite index, European Union.

\section{Introduction}

According to the Lisbon Treaty a particular interest need to be allowed to the European Union as a highly competitive social market economy, seen as a balance between economic freedom and social wellbeing. At the basis of social market economy theory lays the concept of Walter Eucken, according to which the state has the role of establishing a functional legal framework for efficient economic governance, restricting the role of political interventions in the economic process.

In his essay, Wrobel (2012) considers the Social Market Economy as "a socioeconomic model combining a free market capitalist economic system alongside social policies which establish both fair competition within the market and a welfare state".

The basic conception of Social Market Economy "includes a regulatory framework of a functioning price system, monetary stability, freedom of contract and private property, open markets but also the principle of liability and the principle of constancy of economic policy(figure 1). These constitutive principles are accompanied by so-called regulative principles like the necessity of a strict competition policy, internalizing of external effects and a few social measures" (Eucken 1952, pp. 254 - 304).

The fundamental of a Social Market Economy resides in a flexible price system and according to Van Hook (2004), the social market economy combines "private enterprise with regulation and state intervention to establish fair competition, maintaining a balance 
between a high rate of economic growth, low inflation, low levels of unemployment, good working conditions, social welfare, and public services".

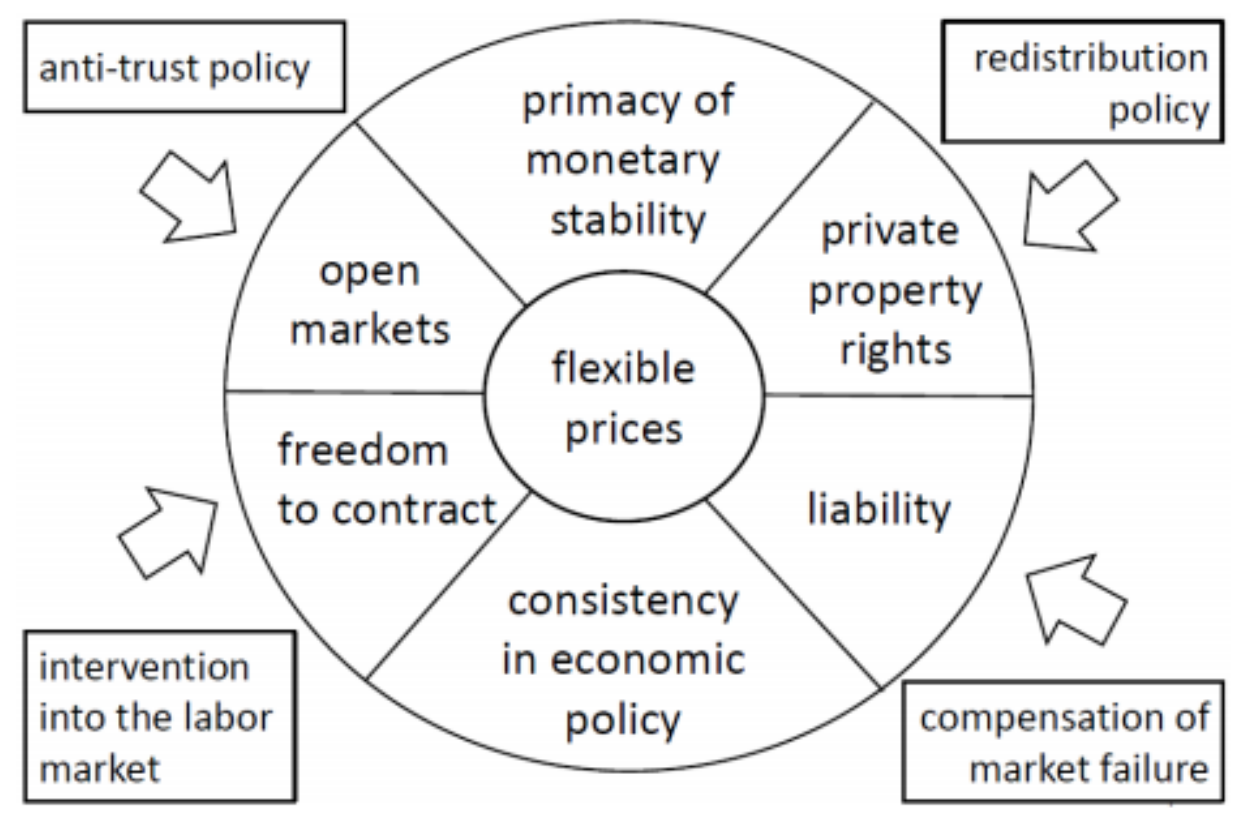

PICBE 228

Figure 1. Fundamentals of the social market economy

Source: Wrobel(2012).

The paper aims to identify the main determiants of the social market economy at European level, by building a composite index using the principal component analysis(PCA) and to analyse comparatively the results of EU countries at the level of 2013.

The paper is organised in the followimg sections: the section of literature review presents the most relevant research results in the field of the social market economy in the literature while the data and methodology section is dedicated to the short presentation of the methodology and data used in the analsyis. The section four presents the main empirical results for $28 \mathrm{EU}$ countries revealing the countries with the highest level of social market economy, as desired economic order specified by the Lisbon Treaty. The paper ends with main conclusions of the study.

\section{Literature review}

Called also "ordo-liberal approach", the concept of social market economy has been developed by Erhard and Eucken in the period 1930-1950 and implies well-being, selfdetermination, freedom and responsibility of individuals. The crisis of Europe in 1920 that deteriorated the free and competitive market, together with a weak state unable to control monopolies leading to a lack of competition created the premises of this new concept.

According to the document of 2009 Congress The Social Market Economy in a Globalized World(2009, p.3), the social market economy is defined as "a concept that combines the efficiency of the market with equal opportunities, an alternative to classic liberalism, which is based on efficiency without equitable development, and to socialism, which rests on equitable development without efficiency". 
Starting from the specification of the Lisbon Treaty according to which the social market economy is seen as "durable European social model", Krabec stated that Central and Eastern countries can achieve development under a social market economy using the constitutive principles of this concept.

At the question "Can the social market economy be the Europe's social model?", Joerges and Rödl (2004) argued that the concept of social market economy is not suitable for the EU.

Attempts to quantify the level of social market economy at European Union have been done by the studies of Helfer(2015), Van Suntum et al.(2012a, 2012b) or Shupe (2012, 2013). Helfer (2015) tried to provide a synthetic measure called the social market economy index taking into account three potential dimensions: political institutional quality, economic institutional quality and societal institutional quality revealing that the Scandinavian countries exhibited the highest scores of social market economy.

Also the study of Van Suntum et al.(2012a, 2012b) elaborated an index of the social market economy taking into consideration Eucken's classic market economy principles classified into four index dimensions using 44 statistical indicators for eight OECD countries revealing that Sweden is the country with the highest level of the social market economy.

Shupe (2012, 2013) measured the modern social market economy using an institutional approach, highlighting Sweden, Germany Netherlands and UK as the main EU social market economies.

Svoboda (2016) analyzed the competencies of EU to respond to social market economy objective revealing that existence of an inverse relationship between these two concepts, although EU competencies are relevant for the majority of social market economy content.

\section{Methodology and data}

The paper aims to highlight the main poles of the social market economy among the $28 \mathrm{EU}$ countries using the principal component analysis (PCA) by building a composite index of the social market economy. Therefore, using PCA we will be able to identify the main determinants of the social market economy at European level and based on these factors we will build one of the first indices of the social market economy available for 28 EU countries.

For the construction of this synthetic measure, we will use the Handbook on Constructing Composite Indicators. The method involved the extraction of latent information from the original variables by identifying from a large number of indicators a smaller number of relevant factors called-principal components who are linear combination of the original variables, uncorrelated and who will recover much of the variance of original variables. In order to select the optimal number of components, Kaiser Criteria was used, based on the value of the eigenvalues greater than 1 .

In the process of constructing the contribution of each factor in the composite index, the proportion of variance recovered by each component in total variance will be used to determine the weights of each factor in the composite index. Studies of Davidescu et. al.(2015), Abdi and Williams(2010), Mourão (2007), Nomikos and MacGregor (1994), Nardo et al.(2005) and $\operatorname{OECD(2008)~presented~the~main~steps~of~building~composite~}$ indices. 
Furthermore, in order to make easier the comparison between EU countries, the composite index was calibrated using percentile rank to take values between 0 (low level of social market economy) and 100(high level of social market economy). The software used in the analysis is SPSS software version 20.

The analysis was based on specific indicators of four main dimensions of social market economy, efficient market allocation, property rights, economic and ecological sustainability and social inclusion at the level of the EU member states for the year 2013.

Furthermore, the variables included in the analysis were: efficient market allocation which traits open markets issues, effective price system and competition, effective property rights-which covers property rights, liability and freedom of contract, economic and ecological sustainability which includes financial stability and economic and environmental policy and lastly social inclusion which traits effective labour markets and social mobility. For the selection of the variables, the study of Shupe (2012) was used as starting point.

For the efficient market allocation, product market regulation proxy for open markets, subsidies and other transfers-proxy for effective price system and media pluralism, media freedom and access to Government information-proxy for competition have been included in the study.

From the second group of indicators-property rights we have used strength of minority investor protection index, intellectual property rights index, corruption prevention, judicial review as proxy for property rights and freedom of contract, strength of insolvency framework index and the ratio of medium size companies to total companies for liability.

The economic stability is a key factor for supporting the effective price system which is at the core of the social market economy. In this context depth of credit information index and bank capital to assets ratio as proxy for financial stability, the extent of staff training, social spending and R\&D spending for economic policy have been included in the study. The component of environmental protection was included also in the analysis through total environmental taxes.

Having in mind that labor market effectiveness and employment status represent a main determinant of well-being and social inclusion, active LMP measures expenditure, EPL index, social inclusion index, education perception index, non-discrimination index proxies for effective labor markets and social mobility were taken into consideration in the analysis.

A short description of the variables used in the analysis together with the data source is presented in appendix A. The main sources of the data used were the specific databases of OECD, World Bank, Eurostat, the indicators of Social Governance Indicators and World Economic Forum.

\section{Empirical results}

In order to solve the existence of different measurement units, standardization of the indicators was required. In order to evaluate the internal consistency of the indicators into a single object, the Cronbach Coefficient Alpha was used (Davidescu et al., 2015). The high value of the coefficient (0.831) proved the utility of building a synthetic measure for social market economy.

Applying the principal component analysis, the empirical results pointed out an optimal number of four principal components which recover almost $78.5 \%$ of total variance 
in the original indicators. In the selection process of optimal principal components, Kaiser Criteria was applied selecting the components with eigenvalues greater than unity.

The empirical results presented in the table 1 revealed that the first principal component recovers an amount of $44.84 \%$ of total variance, while the second one adds another 16.28 percentage, summing up a total amount of recovered variance of almost $61 \%$.The third component recovers another $10.31 \%$ of total variance, while the last one pointed out an additional amount of $7.06 \%$ of total variance.

Table 1. The empirical results of PCA

\begin{tabular}{|c|c|c|c|c|c|c|c|c|c|}
\hline \multicolumn{10}{|c|}{ Total Variance Explained } \\
\hline \multirow[t]{2}{*}{ Component } & \multicolumn{3}{|c|}{ Initial Eigenvalues } & \multicolumn{3}{|c|}{$\begin{array}{l}\text { Extraction Sums of Squared } \\
\text { Loadings }\end{array}$} & \multicolumn{3}{|c|}{$\begin{array}{l}\text { Rotation Sums of Squared } \\
\text { Loadings }\end{array}$} \\
\hline & Total & $\begin{array}{l}\text { \% of } \\
\text { Variance }\end{array}$ & $\begin{array}{l}\text { Cumul. } \\
\%\end{array}$ & Total & $\begin{array}{l}\% \text { of } \\
\text { Variance }\end{array}$ & $\begin{array}{l}\text { Cumul. } \\
\%\end{array}$ & Total & $\begin{array}{|lr|}\% & \text { of } \\
\text { Variance } \\
\end{array}$ & \begin{tabular}{|l} 
Cumul. \\
$\%$
\end{tabular} \\
\hline 1 & 6.726 & 44.842 & 44.842 & 6.726 & 44.842 & 44.842 & 5.242 & 34.945 & 34.945 \\
\hline 2 & 2.443 & 16.287 & 61.129 & 2.443 & 16.287 & 61.129 & 2.725 & 18.165 & 53.110 \\
\hline 3 & 1.547 & 10.314 & 71.444 & 1.547 & 10.314 & 71.444 & 2.312 & 15.413 & 68.522 \\
\hline 4 & 1.059 & 7.063 & 78.506 & 1.059 & 7.063 & 78.506 & 1.498 & 9.984 & 78.506 \\
\hline 5 & .926 & 6.176 & 84.682 & & & & & & \\
\hline 6 & .642 & 4.280 & 88.962 & & & & & & \\
\hline 7 & .423 & 2.818 & 91.779 & & & & & & \\
\hline 8 & .289 & 1.927 & 93.706 & & & & & & \\
\hline 9 & .252 & 1.681 & 95.387 & & & & & & \\
\hline 10 & .190 & 1.268 & 96.655 & & & & & & \\
\hline 11 & .174 & 1.159 & 97.814 & & & & & & \\
\hline 12 & .154 & 1.023 & 98.837 & & & & & & \\
\hline 13 & .092 & .614 & 99.452 & & & & & & \\
\hline 14 & .052 & .350 & 99.801 & & & & & & \\
\hline 15 & .030 & .199 & 100.000 & & & & & & \\
\hline
\end{tabular}

Source: Authors' own research results/contribution

Analyzing the correlations between the principal components and the original indicators presented in the table 2, we can interpret the meaning of the principal components and for this reason we will use a rotation technique called Varimax, which will allow interpreting the principal components in terms of the highest level of correlation with the initial variables. Therefore, each component can be interpreted in terms of the original variables with the highest level of correlation coefficients (Davidescu et al., 2015).

Table 2. Rotated Component Matrix

\begin{tabular}{|r|r|}
\hline & Component \\
\hline
\end{tabular}




\begin{tabular}{|l|c|c|c|c|}
\hline & 1 & 2 & 3 & 4 \\
\hline Zscore: PMR: Product market regulation & -.118 & -.824 & -.199 & .200 \\
\hline Zscore: Media Freedom & .803 & .274 & .202 & -.060 \\
\hline Zscore: Media pluralism & .854 & .035 & .194 & -.141 \\
\hline Zscore: Access to Goverment information & .285 & .296 & .668 & .228 \\
\hline $\begin{array}{l}\text { Zscore: Strength of minority investor } \\
\text { protection index(0-10) }\end{array}$ & .096 & -.173 & .111 & .792 \\
\hline Zscore: Intellectual Property Rights & .575 & .739 & -.224 & -.048 \\
\hline Zscore: Judicial Review & .869 & .154 & .125 & .053 \\
\hline Zscore: Corruption Prevention & .648 & .575 & .176 & .098 \\
\hline $\begin{array}{l}\text { Zscore: Strength of insolvency framework } \\
\text { index(0-16) }\end{array}$ & .249 & -.330 & .795 & -.131 \\
\hline $\begin{array}{l}\text { Zscore: Depth of credit information index } \\
\text { (0=low to 8=high) }\end{array}$ & -.023 & .062 & .924 & -.003 \\
\hline Zscore: Extent of staff training & .681 & .648 & -.194 & -.089 \\
\hline Zscore: Total environmental taxes, \% GDP & -.050 & .015 & -.075 & .823 \\
\hline Zscore: Social Inclusion & .678 & .582 & -.284 & .041 \\
\hline Zscore(Education) & .807 & .070 & .161 & .186 \\
\hline Zscore: Non-discrimination & .787 & .274 & .042 & .037 \\
\hline $\begin{array}{l}\text { Extraction Method: Principal Component Analysis. } \\
\text { Rotation Method: Varimax with Kaiser Normalization. }\end{array}$ & & & & \\
\hline a. Rotation converged in 8 iterations. & & & \\
\hline
\end{tabular}

PICBE 232

Source: Authors' own research results/contribution.

The first component is most correlated with the judicial review (0.869) as proxy for freedom of contract and media pluralism (0.854) proxy for competition. This component can be interpreted in terms of freedom of contract. The second component can be interpreted in terms of product market regulation as proxy for open markets. The third component can be explained by depth of credit information index, which is proxy for financial stability. The fourth component can be defined as a measurement indicator of total environmental taxes, proxy for effective environmental protection.

Therefore, we can conclude that the key determinants in explaining the social market economy at European level can be considered to be freedom of contract, open markets, financial stability and effective environmental protection. 


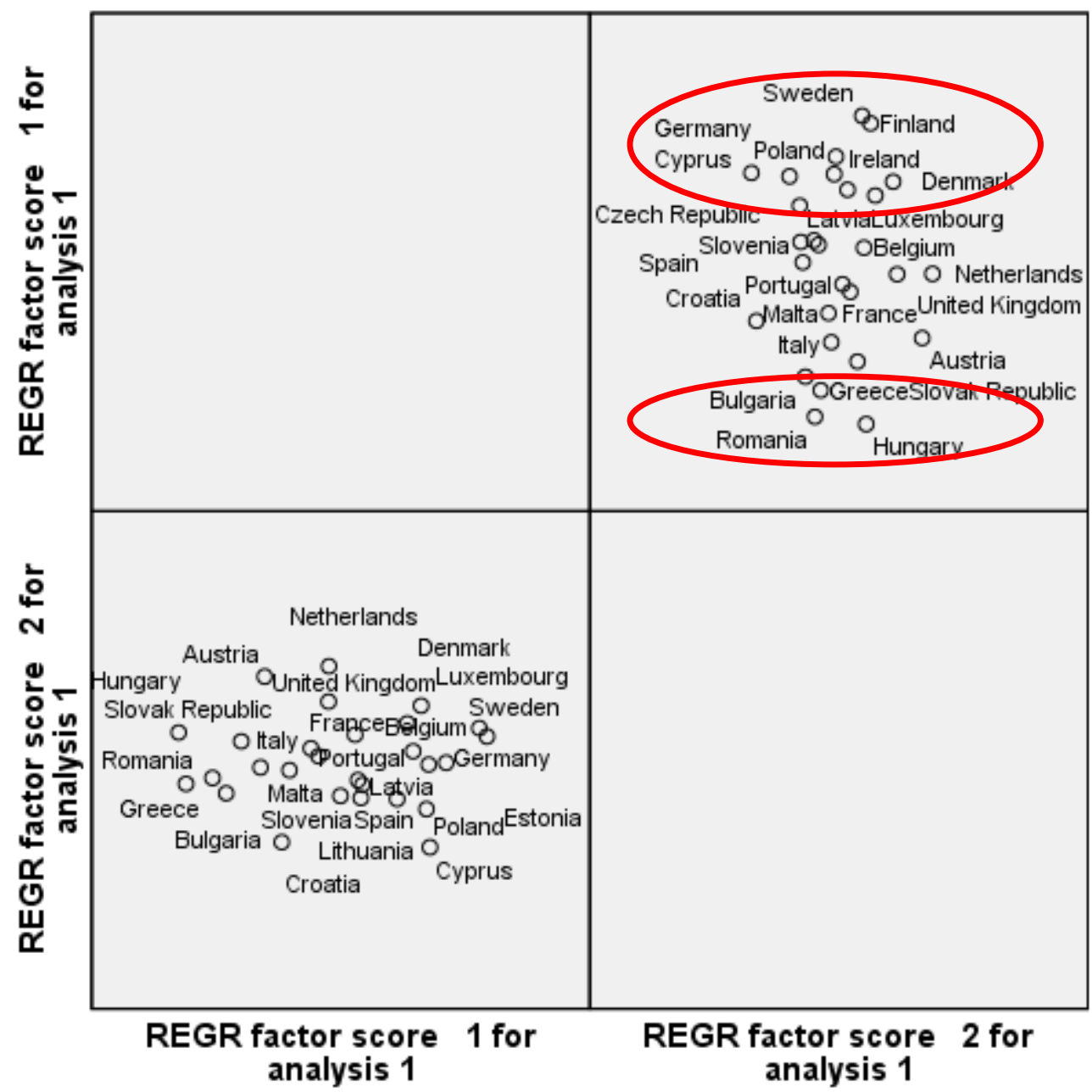

PICBE 233

Figure 2.The distribution of countries in the space of the first two components

Source: Authors' own research results/contribution.

Analyzing the distribution of countries by the first two principal components presented in figure 2, freedom of contract and product market regulation, recovering 61\% of total variance of original variables, the main poles of the social market economy at European level are Sweden, Finland, Germany, Denmark, Ireland, Luxembourg, while on the opposite side are situated Bulgaria, Romania, Hungary, Greece and Slovak Republic.

The quality of the results obtained from PCA has been evaluated with KMO and Bartlett's test of sphericity. The relative high value of Kaiser-Meyer-Olkin (KMO) statistics (0.783) and the statistical significance of Bartlett's test presented in the table 3 highlighted a high level of sampling adequacy proving that PCA is suitable for our purpose of using all these synthetic factors for building a composite index. 
Table 3.The empirical results of KMO and Bartlett's Test

\begin{tabular}{|c|c|c|}
\hline \multicolumn{3}{|c|}{ KMO and Bartlett's Test } \\
\hline \multicolumn{2}{|c|}{$\begin{array}{c}\text { Kaiser-Meyer-Olkin Measure of Sampling } \\
\text { Adequacy. }\end{array}$} & .783 \\
\hline $\begin{array}{c}\text { Bartlett's Test of } \\
\text { Sphericity }\end{array}$ & Approx. Chi-Square & 313.999 \\
\cline { 2 - 3 } & $\mathrm{df}$ & 105 \\
\cline { 2 - 3 } & Sig. & .000 \\
\hline
\end{tabular}

PICBE| 234

Source: Authors' own research results/contribution.

The weights used for capturing the contribution of each component within the index were determined by the proportion of variance recovered by each component in the total variance.

The non-standardized social market economy index is computed as follows:

Non - std.SME_index $=\frac{44.84}{78.50} \cdot P C 1+\frac{16.28}{78.50} \cdot P C 2+\frac{10.31}{78.50} \cdot P C 3+\frac{7.06}{78.50} \cdot P C 4$

In order to facilitate the interpretation the index was transformed using the percentile rank to take values between 0 (low level of social market economy) and 100 (high level). Analyzing the values of the synthetic index of social market economy at the level of 2013 for EU member states, it is worth to notice that almost half of the countries registered a level of social market economy above the EU average (51.78)(see figure 3). The countries with the highest level of social market economy were Sweden, Finland, Denmark, Estonia and Germany. 


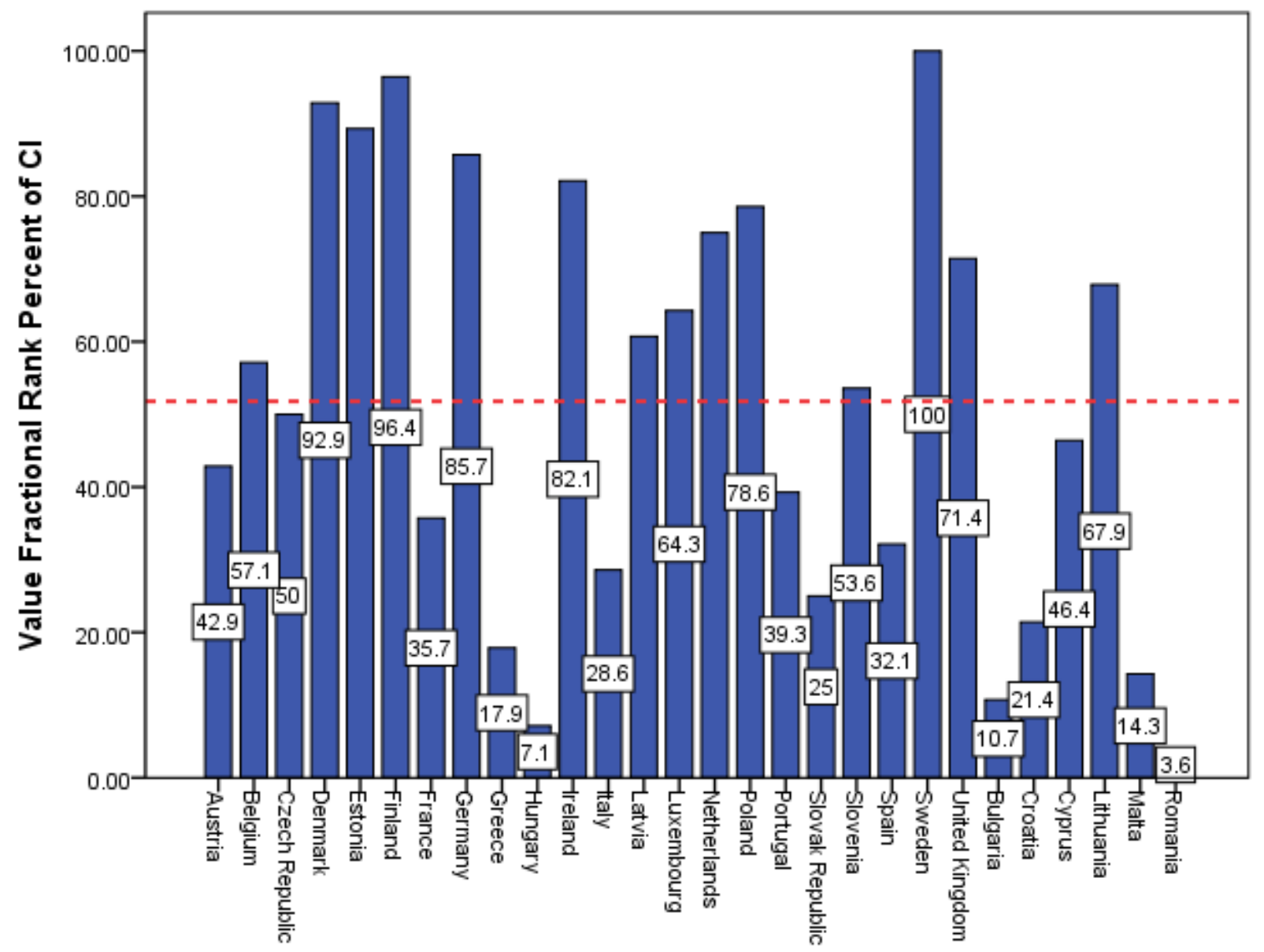

PICBE| 235

Figure 3.The distribution of countries by the level of social market economy

Source: Authors' own research results/contribution.

Highlighting the countries with a low level of social market economy as having a value of the index between 0 and 40, with a medium level for values between 40 and 70 and a high level of social market economy between 70 and 100, it is important to mention that(see figure 4):

$\checkmark$ There are 11 countries with a low level of social market economy among which Romania and Hungary occupied the latest positions, while France and Portugal occupied top positions in this group;

$\checkmark$ There are 8 countries considered as having a medium level of social market economy among which Austria, Cyprus, Czech Republic, Slovenia, Belgium, Latvia, Luxembourg and Lithuania;

$\checkmark$ There are 9 countries with a high level of social market economy among which UK, Netherlands, Poland, Ireland, Germany, Estonia, Denmark, Finland, and Sweden. 


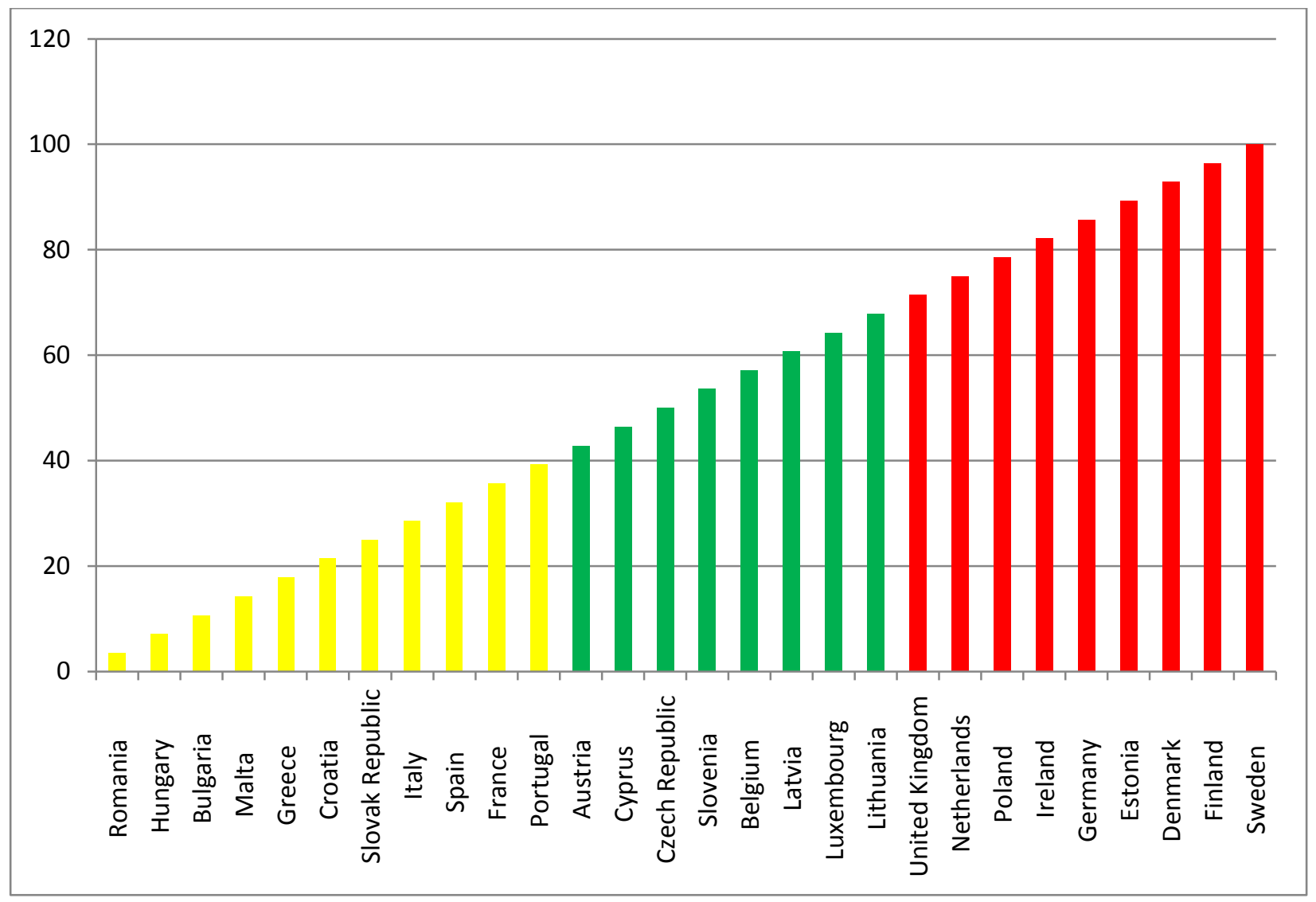

PICBE| 236

Figure 4. The distribution of EU member states by the values of the social market economy index

Source: Authors' own research results/contribution.

The empirical results pointed out the necessity for Romania, Hungary and Bulgaria to improve their level of social market economy, focusing on the main determinants: freedom of contract, open markets, financial stability and effective environmental protection.

\section{Conclusion}

The main objective of the paper was to construct a synthetic measure that can be used as benchmark for measuring the progress toward convergence to social market economy as a fundamental requirement of the Lisbon Treaty. The paper aimed also to analyze the Romanian performances in terms of social market economy in European context.

The analysis included all 28 EU countries at the level for 2013 using specific indicators from four areas: efficient market allocation, efficient property rights, economic and ecological sustainability and also social inclusion.

The empirical results revealed that the key dimensions of the social market economy at European level are freedom of contract, open markets, financial stability and effective environmental protection. Countries with the highest level of social market economy were determined to be Sweden, Finland, Denmark, Estonia and Germany. 
Analyzing the performances of the EU countries in terms of social market economy there can be highlighted three main groups:

$\checkmark$ The group formed by countries with a relative low level of social market economy among which Romania, Hungary and Bulgaria occupied the latest positions, while France and Portugal occupied top positions in this group;

$\checkmark$ The group of 8 countries considered as having a medium level of the social market economy among which Austria, Cyprus, Czech Republic, Slovenia, Belgium, Latvia, Luxembourg and Lithuania;

$\checkmark$ The group of 9 countries considered to have a high level of social market economy among which Sweden, Finland, Denmark, Estonia and Germany occupying the first five positions and considered to be the poles of the social market economy at European level.

The topic being so actual and interesting, it will worth to quantify in the future the performances of EU-28 countries for a period o several years having in mind a panel data techniques called Multi-Way PCA and to evaluate the progress of the EU countries during a certain period of time.

\section{References}

Abdi, H. \& Williams, L. J. (2010). Principal component analysis. Wiley Interdisciplinary Reviews: Computational Statistics 2(4), 433-459.

Davidescu, A. A., Paul, A. M. V., Gogonea, R. M. \& Zaharia, M. (2015). Evaluating Romanian Eco-Innovation Performances in European Context. Sustainability 7(9), 1272312757.

Erhard, L. (1959). Prosperity through Competition. London: Thames \& Hudson.

Eucken, W., \& Eucken, E. (1952). Grundsätze der wirtschaftspolitik.

Helfer, H.(2015).Social market economy: Towards a comprehensive composite index, Discussion Paper, Center for Interdisciplinary Economics, No. 6/2015.

Joerges, C. \& Rödl, F. (2004). 'Social Market Economy'as Europe's Social Model?, EUI Working Paper, no. 2004/8, European University Instutite, Florence.

John, K. D. (2007). The German Social Market Economy-(Still) a Model for the European Union?. Theoretical and Applied Economics, 3(508), 3-10.

Mourão, P. (2007). Towards a Fiscal Illusion Index. MPRA Paper 5091. Munich, Germany: University of Munich. Retrieved from http://mpra.ub.uni-muenchen.de/9760/:

Nardo, M., Saisana, M., Saltelli, A., Tarantola, S., Hoffman, A., \& Giovannini, E. (2005). Handbook on Constructing Composite Indicators: Methodology and User Guide. OECD Statistics Working Papers 2005/3. OECD Publishing. Retrieved from http://ictlogy.net/bibliography/reports/projects.php?idp=2308.

Nomikos, P., \& MacGregor, J. F. (1994). Monitoring batch processes using multiway principal component analysis. AIChE Journal 40(8), 1361-1375.

OECD. (2008). Handbook on Constructing Composite Indicators. Methodology and User Guide. Paris, France: OECD Publications, url: http://oecd.org/std/42495745.pdf.

Shupe, C. (2012). Measuring the Modern Social Market Economy. Future Social Market Economy Policy Brief\# 2012/04. 
Shupe, C. (2013). A European Social Market Economy?-Index Results. Policy Brief\# 2013/03.

Svoboda, P. (2016). Does the EU Have the Competences to Achieve the Objective of a Social Market Economy? (January 5, 2016). Charles University in Prague Faculty of Law Research Paper No. 2015/III/4. Available at SSRN: https://ssrn.com/abstract=2711342 or http://dx.doi.org/10.2139/ssrn.2711342.

PICBE 238

Van Hook, J.C.(2004). Rebuilding Germany: The Creation of the Social Market Economy 1945-1957, Cambridge University Press, 2004, ISBN 0-521-83362-0, p. 185.

Van Suntum, U., Gundel, S., Lurweg, M., Oelgemöller, J. (2012a). Dening a Modern Version of the Social Market Economy. In: Index of Modern Social Market Economy. Explorative Study. Bertelsmann Stiftung, Gütersloh.

Van Suntum, U. et al. (2012b). Methodology. In: Index of Modern Social Market Economy. Explorative Study. Bertelsmann Stiftung, Gütersloh.

Wrobel, R. M. (2012). The social market economy as a model for sustainable growth in developing and emerging countries. Economic and Environmental Studies, 12(1), 47-63.

*** The Social Market Economy in a Globalised World, Congress Document adopted by the EPP Statutory Congress Bonn, 9-10 December 2009, http://www.epp.eu/files/uploads/2015/11/The_Social_Market_Economy_in_a_Glob alised_World.pdf

*** SPSS Software, version 20.

*** Social Governance Indicators, http://www.sgi-network.org/

*** World Economic Forum, https://www.weforum.org/ 


\section{Appendix. The description of the variables}

\begin{tabular}{|c|c|c|}
\hline Principles & Indicators & Data source \\
\hline \multicolumn{3}{|c|}{ Efficient Market Allocation } \\
\hline \multirow[t]{4}{*}{$\begin{array}{l}\text { Open } \\
\text { Markets }\end{array}$} & $\begin{array}{l}\text { Product market } \\
\text { regulation }\end{array}$ & $\begin{array}{l}\text { Market regulation database, } 2013 \\
\text { https://stats.oecd.org/index.aspx?DataSetCode=PMR\# }\end{array}$ \\
\hline & State control & $\begin{array}{l}\text { Market regulation database, } 2013 \\
\text { https://stats.oecd.org/index.aspx?DataSetCode=PMR\# }\end{array}$ \\
\hline & $\begin{array}{l}\text { Barriers to } \\
\text { entrepreneurship }\end{array}$ & $\begin{array}{l}\text { Market regulation database, } 2013 \\
\text { https://stats.oecd.org/index.aspx?DataSetCode=PMR\# }\end{array}$ \\
\hline & $\begin{array}{l}\text { Barriers to trade } \\
\text { and investment }\end{array}$ & $\begin{array}{l}\text { Market regulation database, } 2013 \\
\text { https://stats.oecd.org/index.aspx?DataSetCode=PMR\# }\end{array}$ \\
\hline $\begin{array}{l}\text { Effective } \\
\text { Price System }\end{array}$ & $\begin{array}{l}\text { Subsidies and other } \\
\text { transfers }(\% \text { of } \\
\text { expense })\end{array}$ & WDI database, World Bank \\
\hline \multirow[t]{2}{*}{ Competition } & $\begin{array}{l}\text { Media Pluralism } \\
\text { Media Freedom }\end{array}$ & $\begin{array}{l}\text { Are the media independent and do they express a diversity of } \\
\text { opinions? Is government information accessible? }\end{array}$ \\
\hline & $\begin{array}{l}\text { Access to } \\
\text { Government } \\
\text { information }\end{array}$ & $\begin{array}{l}\text { Sustainabe Governance Indicators, } \\
\text { http://www.sgi- } \\
\text { network.org/2016/Time_Series/Quality_of_Democracy }\end{array}$ \\
\hline \multicolumn{3}{|c|}{ Property Rights } \\
\hline \multirow[t]{2}{*}{$\begin{array}{l}\text { Property } \\
\text { rights }\end{array}$} & $\begin{array}{l}\text { Strength of } \\
\text { minority investor } \\
\text { protection index }(0- \\
10) .\end{array}$ & Doing Business Database, World Bank \\
\hline & $\begin{array}{l}\text { Intellectual } \\
\text { property rights } \\
\text { index }\end{array}$ & $\begin{array}{l}\text { World Economic Forum 2016, } \\
\text { http://internationalpropertyrightsindex.org/countries }\end{array}$ \\
\hline \multirow[t]{2}{*}{$\begin{array}{l}\text { Freedom } \\
\text { contract }\end{array}$} & Judicial Review & $\begin{array}{l}\text { To what extent do independent courts control whether government } \\
\text { and administration act in conformity with the law? } \\
\text { Sustainabe Governance Indicators, } \\
\text { http://www.sginetwork.org/2016/Time_Series/Quality_of_Democracy }\end{array}$ \\
\hline & $\begin{array}{l}\text { Corruption } \\
\text { Prevention }\end{array}$ & $\begin{array}{l}\text { To what extent are public officeholders prevented from abusing their } \\
\text { position for private interests? } \\
\text { Sustainabe Governance Indicators, } \\
\text { http://www.sgi- } \\
\text { network.org/2016/Time_Series/Quality_of_Democracy }\end{array}$ \\
\hline \multirow[t]{2}{*}{ Liability } & $\begin{array}{l}\text { Strength of } \\
\text { insolvency } \\
\text { framework index(0- } \\
\text { 16) }\end{array}$ & Doing Business Database, World Bank \\
\hline & $\begin{array}{l}\text { Ratio of medium } \\
\text { size companies to } \\
\text { total companies }\end{array}$ & Structural business statistics database, Eurostat \\
\hline \multicolumn{3}{|c|}{ Economic and ecological sustainability } \\
\hline \multirow[t]{2}{*}{$\begin{array}{l}\text { Financial } \\
\text { Stability }\end{array}$} & $\begin{array}{l}\text { Depth of credit } \\
\text { information } \\
\text { index(0=low to } \\
8=\text { high) }\end{array}$ & World Bank, Doing Business project (http://www.doingbusiness.org/). \\
\hline & $\begin{array}{l}\text { Bank capital to } \\
\text { assets ratio }(\%)\end{array}$ & WDI database, World Bank \\
\hline
\end{tabular}

DOI: 10.1515/picbe-2017-0024, pp. 227-240, ISSN 2558-9652| Proceedings of the $11^{\text {th }}$ International Conference on Business Excellence 
Economic Extent of staff In your country, to what extent do companies invest in training and Policy training employee development? [1 = not at all; 7 = to a great extent] | 2013-14 weighted average

World Economic Forum, Executive Opinion Survey

http://reports.weforum.org/global-competitiveness-report-2014-

2015/technical-notes-and-sources/

Social Spending, OECD (2017), Social spending (indicator). doi: 10.1787/7497563b-en total net, \% GDP

(Accessed on 11 March 2017).

https://data.oecd.org/socialexp/social-spending.htm\#indicator-chart

Gross domestic Statistics on research and development database, Eurostat

expenditure on http://appsso.eurostat.ec.europa.eu/nui/setupDownloads.do

R\&D (GERD) - \% of

GDP

\section{Enivromental Total \\ Protection environmental \\ taxes \\ $\%$ GDP}

Enviromental policy
Environmental tax revenues database, Eurostat

How effectively does environmental policy protect and preserve the sustainability of natural resources and quality of the environment?

Sustainable Governance Indicators,

http://www.sgi-

network.org/2016/Time_Series/Environmental_Policies

\begin{tabular}{|c|c|c|}
\hline \multicolumn{2}{|c|}{ Social Inclusion } & 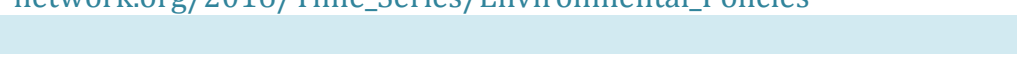 \\
\hline \multirow{4}{*}{$\begin{array}{l}\text { Effective } \\
\text { Labour } \\
\text { Markets }\end{array}$} & Active $\quad$ LMP & Labour market policy database, Eurostat \\
\hline & measures & \\
\hline & expenditure, \% GDP & \\
\hline & $\begin{array}{l}\text { Strictness } \\
\text { employment } \\
\text { protection } \\
\text { individual } \\
\text { collective } \\
\text { dismissals (regular } \\
\text { contracts) Version } 3 \\
2008-2013\end{array}$ & $\begin{array}{l}\text { Employment Protection Database, OECD } \\
\text { http://stats.oecd.org/Index.aspx?DataSetCode=EPL_R }\end{array}$ \\
\hline \multirow[t]{3}{*}{$\begin{array}{l}\text { Social } \\
\text { Mobility }\end{array}$} & Social inclusion & $\begin{array}{l}\text { Do welfare policies foster equal opportunity in society and prevent } \\
\text { poverty? } \\
\text { Sustainable Governance Indicators, } \\
\text { http://www.sgi-network.org/2016/Time_Series/Social_Policies }\end{array}$ \\
\hline & $\begin{array}{l}\text { Education } \\
\text { perception }\end{array}$ & $\begin{array}{l}\text { Does education policy deliver high-quality, equitable education and } \\
\text { training? } \\
\text { Sustainable Governance Indicators, } \\
\text { http://www.sgi- } \\
\text { network.org/2016/Policy_Performance/Social_Policies/Education }\end{array}$ \\
\hline & Non-discrimination & $\begin{array}{l}\text { How effectively does the state protect against different forms of } \\
\text { discrimination? Sustainable Governance Indicators, } \\
\text { http://www.sgi- } \\
\text { network.org/2016/Time_Series/Quality_of_Democracy }\end{array}$ \\
\hline
\end{tabular}

\section{PICBE| 240}

